\title{
The use of natural soil for the treatment of secondary effluent in a northern climate
}

\author{
Janusz A. Szpaczyński ${ }^{1, *}$ \\ ${ }^{1}$ Wrocław University of Science and Technology, Wrocław, Poland
}

\begin{abstract}
The aim of this study was to evaluate atomizing freeze crystallization as a valuable option for land application of pre-treated wastewater. Process factors, such as the concentration of nitrogen compounds, phosphorus and conductivity have been adopted as parameters of concern and were used to assess the effectiveness of the freeze crystallization process. Five monitoring wells were installed to control the ground water quality at the site and at its boundaries. It was found that there is no dissolved phosphorus in the ground water. In most measurements, available phosphorus for plants was not detected at a soil depth greater than 50 $\mathrm{cm} . \mathrm{NO}_{3}{ }^{-}-\mathrm{N}$ in ground water from the up gradient well and from the down gradient wells was not detected in most sampling events. There was a small increase of $\mathrm{NO}_{3}^{-}-\mathrm{N}$ near the location of the main snowpack, but it was always lower than the drinking water standard. Total ammonia as $\mathrm{N}$ in the up gradient control well was at the same level as in the down gradient well. Unfortunately, higher conductivity was reported in all down gradient wells. These conductivity values did not imply risks for vegetation yields or the texture of soil. It was concluded that the method of freezing effluent in the form of man-made snow proved to be effective for cold climate land application treatment.
\end{abstract}

\section{Introduction}

In a northern climate, low temperatures can significantly impact the efficiency of biological wastewater treatment processes. Systems with lagoons and spray irrigation operations are particularly vulnerable. Reduced activity and reproduction of aquatic and soil microbes, as well as the dormancy of vegetation at low temperatures, create unfavorable conditions for the treatment of wastewater and, in some cases, may reduce it to an unacceptable minimum. Unfortunately, lagoon and irrigation systems are often located in northern rural areas because they are well suited to small communities where land is usually available and where low wastewater purification costs are one of the main criteria for selection of the technology.

Effluent application on land is practiced to achieve high quality treatment and in some cases, the reuse of nutrients contained in wastewater [1]. The spray irrigation system uses soil as a porous medium for physical and biochemical filtration. The processes that occur in the soil profile are responsible for the purification of the applied effluent. However, the land application system can only be used in accordance with regulations during a period when developed vegetation can uptake nutrients. During winter months in cold climates, spray irrigation and discharge of an effluent from lagoons into local lakes or tributaries is usually prohibited. Spray irrigation is only applied in the warmer months of spring, summer and in early fall. Therefore, any development of a village or municipality requires an increase in the capacity of lagoons and the storage time of wastewater during winter months. A possible option is to choose a more complex operation, such as an activated sludge system, however this increases the costs of building the system and wastewater treatment.

The idea of converting lagoon effluent into man-made snow for winter storage and treatment can solve the problem. The concept is not new and appeared after the first trial that was done by the Upper Yampa Water Conservation District of Colorado and Wright-McLaughlin Engineers [2]. The purpose of the study was to evaluate the use of sewage effluent for snowmaking on ski slopes. A significant contribution to the development of the technology was made by Huber and Palmateer [3] and White $[4,5]$. The authors have carried out extensive studies of wastewater properties after freezing by atomization in cold air. Particular emphasis was placed on the bacteriological aspects of freezing and the chemical properties of melt water.

In recent years, there has been increased interest in freeze crystallization systems [6-10]. To date, a series of small and full-scale tests of freezing of municipal and industrial wastewater in the form of man-made snow or bulk ice has been carried out. Several spray irrigation plants use atomizing freeze crystallization (AFC) to avoid

\footnotetext{
Corresponding author: j.a.szpaczynski@gmail.com
} 
winter treatment and surface discharge. Currently, most of them are located in the United States. In Maine the freeze crystallization plants are in the following cities: Carrabassett Valley [11-12, 5], Mapleton, Greenville, Rangeley and Mars Hill. There is also a freeze crystallization plant in Island Park, Idaho. The plant in Mars Hill treats wastewater from a potato processing plant. It is the first industrial application of the atomizing freeze crystallization system. There is also one system for treatment of landfill leachate that uses irrigation in the summer and atomizing freeze crystallization in the winter. The plant is located in Chester, NS, Canada [13]. For pretreatment, the system uses long-term aeration and biofiltration. The effluent from this system is disposed of by land application throughout the year.

In the AFC process, during cold winter months, the secondary effluent is converted into man-made snow and is deposited on the ground. Several physical processes take place during atomization and, after snow deposition, inside the snowpack $[14,15,7]$. In spring, the natural snow melts first. Man-made snow melts much slower. This is due to the lower porosity of the man-made snow and the mass of the snowpack, which depends on the volume of processed wastewater. This extended melting of the man-made snow is beneficial for the process because melt water is released slowly into the soil.

The beneficial effect of freezing is based on the fact that the crystallographic structure of the ice makes it difficult to absorb contaminants in the form of solid or dissolved compounds $[16,17]$. The ice crystal grows by attaching water molecules. Particles of impurities and ionic compounds can be trapped in ice, but for the most part, impurities are rejected by the ice and are gradually pushed against its growing front.

With slow freezing under natural conditions, most of the small solid phase particles are pushed away from the growing crystal. The movement of particles and their concentration in the vicinity of the interfacial boundary causes their mutual contact over time. Then, under high pressure produced by ice, the energy barrier is overcome and the solid particles agglomerate to form clusters larger than the individual particles. Finally, after thawing, these clusters of particles are more easily separated from liquid $[18,10]$.

On the macro scale, snow produced by man does not resemble natural snow. It consists of frozen water droplets rather than flakes. The freezing of effluent in the form of man-made snow creates similar conditions as standard freezing in thin layers. After wastewater atomization, the ice crystals first form from the pure water at the surface of each droplet. Dissolved compounds such as salts and gases, as well as solid particles are trapped in the ice globule. Growing further ice crystals incorporate water molecules and concentrate compounds in the remaining liquid inside the droplet. When the solubility of the gaseous compounds reaches maximum and oversaturation takes place, gas bubbles nucleate and are trapped between the growing ice crystals inside the ice shell. An analogous situation occurs with other compounds and some salts may precipitate.

The method of freezing in the form of snow proved to be effective not only in reducing the concentration of some undesirable compounds but, through the agglomeration of colloidal particles, significantly improving the clarity of treated wastewater [10].

Although several studies have been devoted to the concept of freezing wastewater in the form of man-made snow, there is still insufficient data on nutrients leaching into the ground water. The aim of this study was to evaluate atomizing freeze crystallization as a valuable option for land application of pre-treated wastewater. Process factors, such as the concentration of nitrogen compounds, phosphorus and conductivity have been adopted as parameters of concern and were used to assess the effectiveness of the freeze crystallization process and its effect on the quality of the ground water at the snow deposit site.

\section{Materials and methods}

\subsection{The snow deposit site}

Effluent from the lagoon system was used for the production of man-made snow. High pressure, two phase atomizing nozzles were operated. Several snowmaking towers were placed on the site so as to uniformly distribute the snow over the entire subject area. Each tower was about $10 \mathrm{~m}$ high.

The size of the snow deposit site, without the buffer zone, was about 7 ha. It was covered with grass and weeds. The grass showed a favorable response to the melt of the snowpack and caught up quickly where large snow piles had delayed the growing season (Fig. 1). The slow melting of the man-made snow was advantageous because the melt water gradually infiltrated into the ground. Fig. 1 shows the snowpack at the end of melting in June. The vegetation is well developed and reaches the edges of the main snowpack.

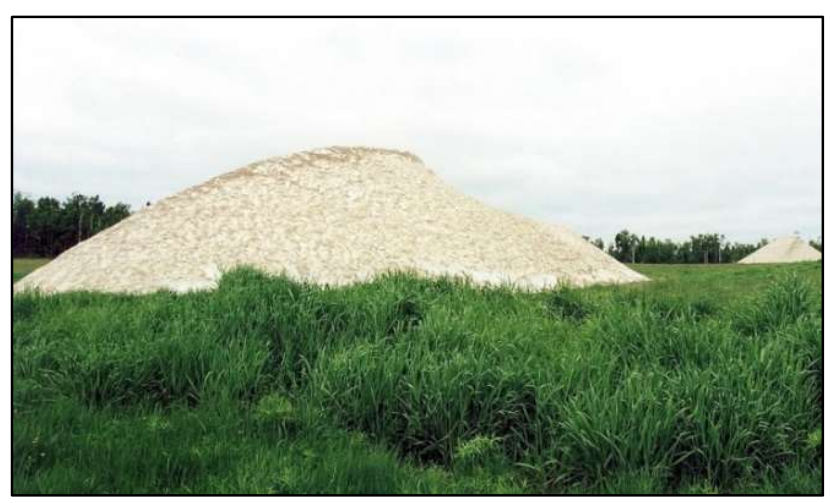

Fig 1. Man-made snowpack at the end of melting 
It should be noted that the grasses transpire large amounts of water, even if there is a water deficiency. Weeds were tolerated on the field to introduce biodiversity and ensure the presence of root systems of plants at different depths of the soil. Maintaining many different kind of weeds and grasses provides greater diversity of nutrient uptake. Once a year, the vegetation on the snow storage area was cut down and removed.

The area was surrounded by a buffer area with trees and shrubs. The buffer zone restrained the drift of the small ice crystals produced at the designated area and protected the surrounding properties from the deposition of effluent in the form of man-made snow. The vegetation of the buffer zone has a high capacity to prevent the movement of nitrate and other nutrients in ground water flow. Trees and shrubs with a deep root system uptake significant amount of nutrients and can transpire a substantial volume of water [19]. The buffer zone was created from a natural forest. It was about $80 \mathrm{~m}$ wide. The area was dominated by trees such as aspen, maple, willow and ash. Most of them are resistant to the periodic occurrence of wet conditions in the soil and uptake and store large quantities of nutrients. Shrubs provided additional cover beneath the tree canopy and were also effective in removing nutrients from the soil and provided an effective barrier for the drift of ice crystals.

To distribute the meltwater over the entire surface of the snow deposit site, 5 shallow ditches were dug. This prevented soil erosion and distributed the meltwater throughout the area. There was a slope (about 4\%) at the site. This suggests the direction of ground water flow.

\subsection{Monitoring}

Five monitoring wells were used to control the ground water quality at the site and at its boundary (Fig. 2).

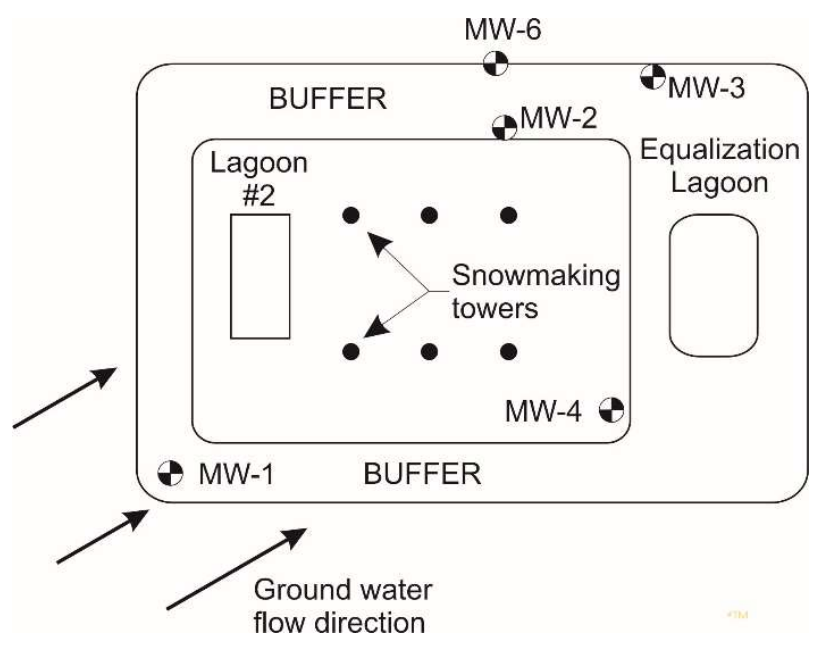

Fig. 2. Location of monitoring wells

One well was installed at the highest elevation at the property boundary. It was considered as a background well MW \#1. Two wells (MW \#2 \& MW \#4) were installed inside the property near the area where man-made snow was deposited. Well MW \#2 was located in the vicinity of the snow deposit site, at the inside edge of the buffer area. Well MW \#4 was installed at the snow deposit site, about $70 \mathrm{~m}$ from the main snowpack. There was no buffer zone between this well and the snow storage area. Both monitoring wells, MW \#2 and MW \#4, are internal wells and not located at the property boundary. The well that was installed at the lowest elevation at the property boundary was described as a down gradient well and was marked as MW \#3. This well was within the boundaries of the considered area, but behind the buffer zone. At the edge of the property, also behind the buffer zone, well MW $\# 6$ is located. Well MW \#5, positioned only a few meters from MW \#6, was not used for monitoring. Well MW \#6 was installed later than the others. The purpose of the well at this location was to assess the quality of ground water at this edge of the property.

It can be assumed with sufficient probability, that the ground water moves from the point of the location of well MW \#1 through the snow deposit site, buffer area and the location of well MW \#6, as well as in the direction of the lowest point on the site, where well MW \#3 was installed (Fig. 2). The water table at the location of well MW \#3 is usually shallow and the soil in that area is periodically saturated in the spring.

The effluent from the lagoon that was used for the production of the man-made snow was sampled and analyzed several times each year (Table 1). Moreover, before the snowmaking operation took place, the ground water from all monitoring wells was collected 4 times during a one-year period and analyzed for basic parameters. Each sampling event took place in a different month. The results are presented in Tables 2, 3, and 4.

Table 1. Effluent from the lagoon (average values)

\begin{tabular}{|c|c|c|c|}
\hline Total P & $\begin{array}{c}\text { Total } \\
\text { Ammonia } \\
-\mathrm{N}\end{array}$ & TKN & Conductivity \\
\hline $\mathrm{mg} / \mathrm{l}$ & $\mathrm{mg} / \mathrm{l}$ & $\mathrm{mg} / \mathrm{l}$ & $\mu \mathrm{S} / \mathrm{cm}$ \\
\hline 2.71 & 9.75 & 21.5 & 1365 \\
\hline
\end{tabular}

The soil varied on the snow deposit site. The top layer of a few centimeters contained fine sand and organic matter. The next layers contained fine sand and silt over clay. Cobble and boulder till were reported deeper. Bedrock in the locations of MW \#1, MW \#2, MW \#3, MW \#4 and MW \#6, mainly grey and greenish-grey limestone, was reported at the depth of $6.1 \mathrm{~m}, 1.3 \mathrm{~m}, 4.6 \mathrm{~m}, 3 \mathrm{~m}$ and $3.9 \mathrm{~m}$, respectively.

Each year, in the full-scale operation, about $70.000 \mathrm{~m}^{3}$ of secondary effluent was converted to man-made snow and deposited on an area of about 7 ha. Part of it sublimated during snowmaking and after deposition from the snowpack [20]. The melting usually ended at the end of June. This depended on weather conditions, particularly 
the levels of solar radiation, temperature and precipitation, as well as the mass and distribution of the man-made snow at the site.

Melt water was released slowly as the pile of snow melted. The melting process was so slow that the grass grew about $1 \mathrm{~m}$ from the pile of snow and quickly occupied every centimeter of the land released from the snow (Fig. 1).

Organic solid particles as well as precipitated complexes were deposited on the surface. Dissolved compounds infiltrate into the soil. Some of them are mobile in soil pores but they are removed by the phytoremediation process. Some others, for example phosphorus, are fixed and absorbed in the soil profile and should not leachate into the ground water. Organic compounds biodegrade in the top layer of soil.

To investigate possible leaching of phosphorus that is available for plants and its deposition in the upper layer of soil, changes of its concentration at $0-100 \mathrm{~cm}$ soil profile, were analysed at two locations. The first place was chosen near the tower, where the most snow was stored during the winter. The second place was selected about $70 \mathrm{~m}$ from the snowmaking tower. The snowpack was relatively shallow there. At both locations, after a period of melting when the site was covered by vegetation, two holes, each about 1.5 $\mathrm{m}$ deep, were excavated in the ground. Soil samples were taken from the side wall at various depths.

Phosphate available for plants was represented by sodium bicarbonate extractable phosphorus [21]. The results of the analyses are presented in Fig 3.

Furthermore, every month, ground water from the monitoring wells was sampled and analysed for dissolved phosphorus and nitrogen compounds. All ground water samples were delivered to an accredited laboratory and analysed the same day they were collected. All analyses were carried out in accordance with the applicable standard methods for the examination of water and wastewater [22].

To evaluate the path of ground water movement as well as the amount of dissolved salts, conductivity of ground water was also checked in all monitoring wells.

Although some ponded water can be located at the snow deposit site during the melting season, no direct discharge of surface water was present during the monitoring period. Therefore, only ground water data was considered in this paper and the analysis was limited to the parameters of concern, i.e. nitrate, ammonia, phosphorus as well as conductivity. All collected groundwater samples were filtered on $0.45 \mu \mathrm{m}$ filters prior analysis.

\section{Results and discussion}

\subsection{Phosphorus}

Dissolved phosphorus in all monitoring wells before the first year of snowmaking operation was not detected in ground water $(\mathrm{MDL}=0.01 \mathrm{mg} / \mathrm{l})$.
Two different mechanisms are responsible for restraining phosphorus compounds from leaching into the ground water table. The first is fixation and the second is phosphorus uptake by plants as a nutrient. Fixation takes place when phosphate reacts with other minerals to form insoluble compounds. In acidic soils the phosphate is fixed by iron and aluminum oxides [23]. In neutral and alkaline soils, iron and aluminum compounds are insoluble and phosphate reacts with calcium to form calcium phosphate. An abundance of calcium is necessary. Fortunately, calcium is present in the soil as well as in the meltwater and is delivered for transformation of dissolved phosphorus into the insoluble forms. This form is usually not available for plants. The phosphorus taken up by plants is in the form of ions. Because the average $\mathrm{pH}$ of soil at the snow deposit site was about 7.6, ions such as $\mathrm{HPO}_{4}{ }^{2-}$ and $\mathrm{H}_{2} \mathrm{PO}_{4}^{-}$dominate at that site.

Both mechanisms as well as the immobilization of $\mathrm{P}$ by soil microorganisms ensure that $\mathrm{P}$ does not leak into the water table and is stopped, mainly in the top layer of the soil, by the above-mentioned mechanisms. This is confirmed by the results of the experiment that was done (Fig 3). Phosphorus available for plants decreases with increasing depth of the sampling point. Below about 50 $\mathrm{cm}$, phosphate immobilization was completed - $\mathrm{NaHCO}_{3}$ extractable $\mathrm{P}$ was at the range of the method detection limit - MDL.

At a distance of about $70 \mathrm{~m}$ from the main snowpack, soil analyses revealed only trace concentrations of sodium bicarbonate extractable phosphorus. This can be observed from the graph (Fig. 3).

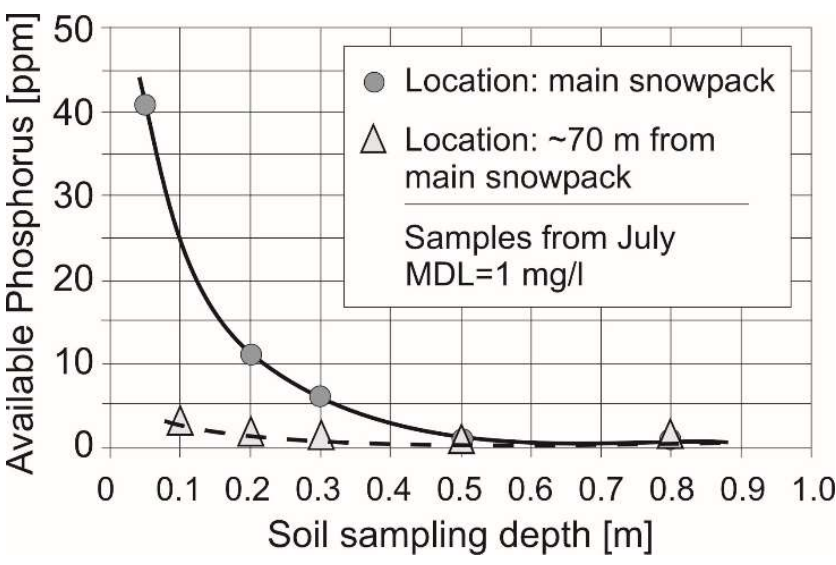

Fig. 3. Sodium Bicarbonate Extractable Phosphorus vs. depth of the soil.

Only in close distance from the snowmaking tower, $\mathrm{P}$ available for plants was noticed at higher concentrations and only to the depth of about $50 \mathrm{~cm}$. Phosphorus accumulation in the upper soil layer was also observed by Tzanakakis et al. [24].

Dissolved phosphorus was quickly consumed and immobilized by fixation. Because average $\mathrm{pH}$ of the soil was 7.6, the most probable type of phosphorus at evaluated site was calcium phosphate [23]. No leaking of phosphorus 
to the ground water was reported. The results of the experiment indicate that the phosphate was fully restrained in the soil profile.

Ground water analyses in all monitoring wells showed that for approximately one hundred measurements, carried out over the entire monitoring period of several years, only in two samples in MW \#2 was the phosphate concentration higher than MDL. It was reported as low as $0.06 \mathrm{mg} / \mathrm{l}$ and $0.04 \mathrm{mg} / \mathrm{l}$. In the remaining measurements for all other wells, phosphate was not detected in ground water. Concentration of phosphorus in the effluent that was used to make snow was low (Table 1) and it was in the range of phosphorus uptake by vegetation [25]. Considering the above, as well as phosphorus precipitation during freeze/thaw process and its fixation in the top layer of the soil, it was assumed that dissolved phosphorus did not leach into the water table. Therefore, in later years phosphorus in the ground water samples was no longer analysed.

\subsection{Nitrogen compounds}

Nitrate is highly mobile in soil and it is a health related parameter therefore, it was considered for analyses. The second nitrogen compound selected for monitoring was ammonia.

\subsubsection{Nitrate $\mathrm{NO}_{3}{ }^{-}-\mathrm{N}$}

A year before the launch of the operation of man-made snow production from secondary effluent, the $\mathrm{NO}_{3}{ }^{-}-\mathrm{N}$ concentration was tested in four monitoring wells. The results are presented in Table 2.

Table 2. Nitrate as $\mathrm{N}$ in ground water before snowmaking operation, (MDL $=0.10 \mathrm{mg} / \mathrm{l})$.

\begin{tabular}{|c|c|c|c|}
\hline MW \#1 & MW \#2 & MW \#3 & MW \#4 \\
\hline$[\mathrm{mg} / 1]$ & {$[\mathrm{mg} / \mathrm{l}]$} & {$[\mathrm{mg} / \mathrm{l}]$} & {$[\mathrm{mg} / 1]$} \\
\hline 1.1 & 0.16 & 0.97 & 0,44 \\
\hline N/A & 0.12 & 0.02 & 0,27 \\
\hline$<0.10$ & 0.11 & $<0.10$ & 0,85 \\
\hline$<0.10$ & 0.32 & $<0.10$ & 0,56 \\
\hline
\end{tabular}

Several times each year during the whole monitoring period, the ground water samples from the same wells were analysed for the presence of $\mathrm{NO}_{3}{ }^{-}-\mathrm{N}$. The ground water research results presented in figures $4,5,6$, and 7 refer to 11 years of operation and monitoring. The limit of $10 \mathrm{mg} / \mathrm{L}$ for nitrate is a primary drinking water standard. In up gradient location (MW $\# 1$ ), $\mathrm{NO}_{3}{ }^{-}-\mathrm{N}$ was not detectable in most sampling events. Only 3 times was the concentration of $\mathrm{NO}_{3}{ }^{-}-\mathrm{N}$ in this well reported above the method detection limit $\mathrm{MDL}=0.10 \mathrm{mg} / \mathrm{l}$ but did not exceed $0.2 \mathrm{mg} / \mathrm{l}$ (Fig. 4).

Similar results were obtained for the down gradient well MW \#3 (Fig. 6). For over 11 years of ground water monitoring at this location, the majority of time the $\mathrm{NO}_{3}^{-}-$ $\mathrm{N}$ was below the MDL. Only two times $\mathrm{NO}_{3}{ }^{-}-\mathrm{N}$ reached a value of about $1.2 \mathrm{mg} / \mathrm{l}$ and $1.0 \mathrm{mg} / 1$.

Monitoring well MW \#2 was located on the edge of the buffer zone near the storage area of man-made snow. Well MW \#6 was located at the same direction of ground water flow but behind the buffer zone. Well MW \#2 does not represent ground water leaving the site. Both wells MW\#6 and MW\#3 are located near the property border and these wells represent ground water flowing out of the site. During several years of operation and monitoring ground water quality, there appears to be a small amount of nitrate leaching as shown by increases in nitrate levels in well $\mathrm{MW} \# 2$. The analysis of ground water in this well, for $\mathrm{NO}_{3}{ }^{-}$ -N content, showed small concentrations ranging from 0 to a maximum of about $4 \mathrm{mg} / \mathrm{l}$. This is much lower than the current drinking water standard.

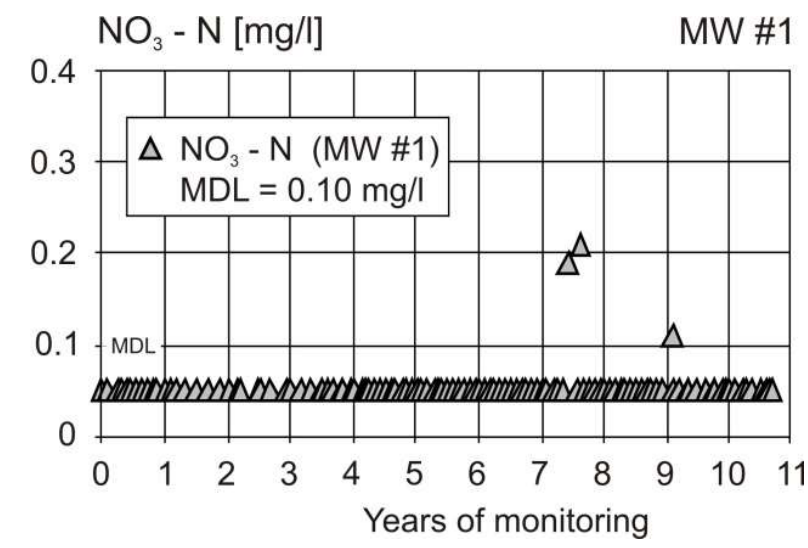

Fig. 4. Concentration of $\mathrm{NO}_{3}^{-}-\mathrm{N}$ in ground water of up gradient well MW \#1

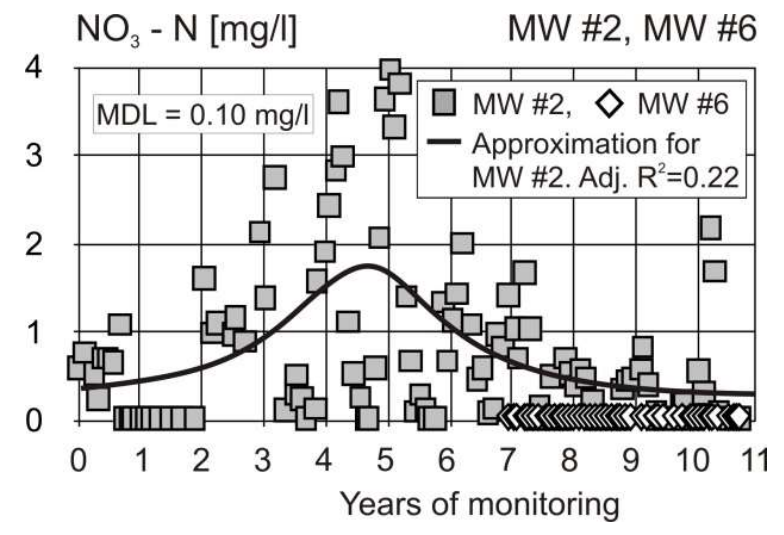

Fig. 5. Concentration of $\mathrm{NO}_{3}^{-}-\mathrm{N}$ in ground water of both wells MW \#2 \& MW \#6

In the first years of the process, the concentration of NO3-N in MW \#2 increased slightly. After about 5 years, there was a downward trend (Fig. 5). This phenomenon can be explained by the abundant development of vegetation in the area. These results can be compared to the MW \#6 well, which is in the same direction of ground water flow. 
Undetectable $\mathrm{NO}_{3}{ }^{-}-\mathrm{N}$ concentrations in MW \#6 (Fig. 5) may suggest that nitrates present in the location of MW \#2 were taken up by trees and other vegetation in the buffer zone. Nitrogen compounds taken up by plants are stored in the tissues of the plants.

Nitrate is also broken down in shallow ground water in the forested area through a process of denitrification. In this process bacteria transform the nitrate to nitrogen gas, which is then released to the atmosphere. However, this can only occur if there is an anaerobic condition in the soil and labile carbon is available. Anaerobic condition in the soil of forested areas may be present for some periods of time. Labile carbon is also available. Therefore, it can be hypothesized that ground water flowing through the buffer zone was purified The nitrate $\mathrm{NO}_{3}{ }^{-}-\mathrm{N}$ was not detected in the monitoring well (MW \#6) behind the buffer zone.

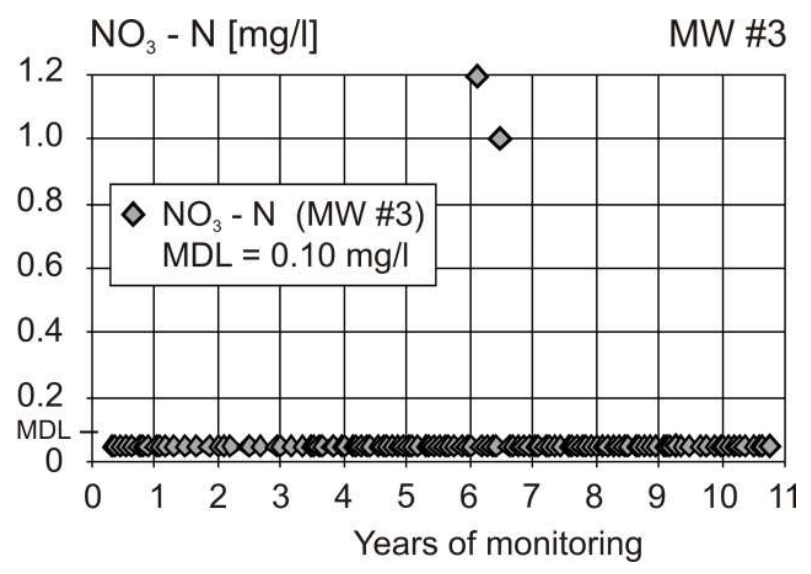

Fig. 6. Concentration of $\mathrm{NO}_{3}^{-}-\mathrm{N}$ in ground water of down gradient well MW \#3

$\mathrm{NO}_{3}-\mathrm{N}[\mathrm{mg} / \mathrm{l}]$

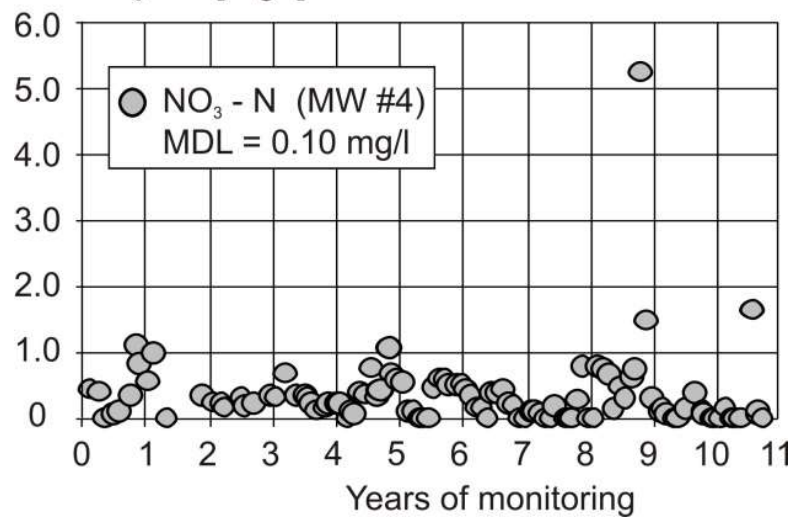

Fig. 7. Concentration of $\mathrm{NO}_{3}^{-}-\mathrm{N}$ in ground water mid-system well MW \#4.

The monitoring well MW \#4 is situated near the area of the main snowpack location and is not at the property boundary behind the buffer zone. The samples from this well do not represent the ground water leaving the site. However, most of the analysed samples showed $\mathrm{NO}_{3}{ }^{-}-\mathrm{N}$ concentrations below $1 \mathrm{mg} / \mathrm{l}$ (Fig. 7). Only in three samples concentration of $\mathrm{NO}_{3}{ }^{-}-\mathrm{N}$ was in the range from $1.52 \mathrm{mg} / \mathrm{l}$ to $5.29 \mathrm{mg} / \mathrm{l}$.

Generally, there was no tendency of increased nitrate in the ground water. However, there were some fluctuations of nitrate concentration in the ground water in the area of the snow deposit site. The results for monitoring wells MW \#1, MW \#3 and MW \#6 indicate that the melt water at the snow deposit site has no negative effect on the $\mathrm{NO}_{3}$ $-\mathrm{N}$ concentration in the ground water leaving the property.

\subsubsection{Total Ammonia (TAN)}

Concentrations of TAN before production of man-made snow, for each monitoring well, are presented in Table 3.

The results for TAN evaluation in ground water during the snowmaking operation in monitoring wells MW \#1, MW \#2, MW \#3 and MW \#4 are presented in Fig. 8, 9, 10 and 11 , respectively. There is no correlation for this data and $\mathrm{Adj} . \mathrm{R}^{2}$ is below reasonable application.

Table 3. Total Ammonia as $\mathrm{N}$ before snowmaking operation $(\mathrm{MDL}=0.02 \mathrm{mg} / \mathrm{l})$

\begin{tabular}{|c|c|c|c|}
\hline MW \#1 & MW \#2 & MW \#3 & MW \#4 \\
\hline$[\mathrm{mg} / \mathrm{l}]$ & {$[\mathrm{mg} / \mathrm{l}]$} & {$[\mathrm{mg} / \mathrm{l}]$} & {$[\mathrm{mg} / \mathrm{l}]$} \\
\hline N/A & $<0.02$ & $<0.02$ & 0.4 \\
\hline 0.07 & 0.04 & 0.05 & 0.04 \\
\hline 0.04 & 0.08 & 0.02 & $<0.02$ \\
\hline
\end{tabular}

The fact that the concentration of total ammonia in the majority of samples collected during several years of ground water monitoring was basically in the same range for both wells MW \#1 and MW \#3 suggests that there is no ground water contamination by ammonia as a result of the use of secondary effluent in the form of man-made snow.

Total Ammonia - N (TAN) [mg/l]

MW \#1

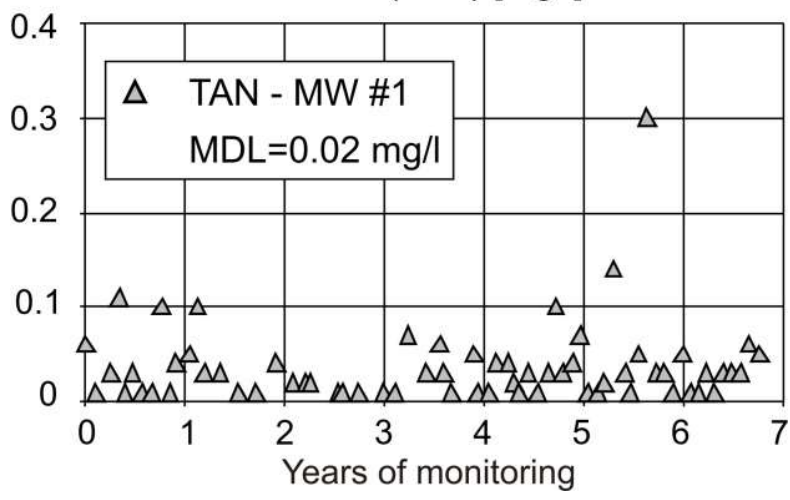

Fig. 8. Concentration of TAN in ground water of up gradient well MW \#1

Moreover, an analysis of concentrations of total ammonia in both wells MW \#2 and MW \#4 located at the site, revealed that in most cases, the total ammonia in the ground water directly at the site was below MDL (Fig. 9 and Fig. 11). Slightly higher concentrations of total 
ammonia in up gradient well MW \#1 and down gradient well MW \#3 could be a result of decomposition of forest litter and some trace leaching of ammonia into the water table.

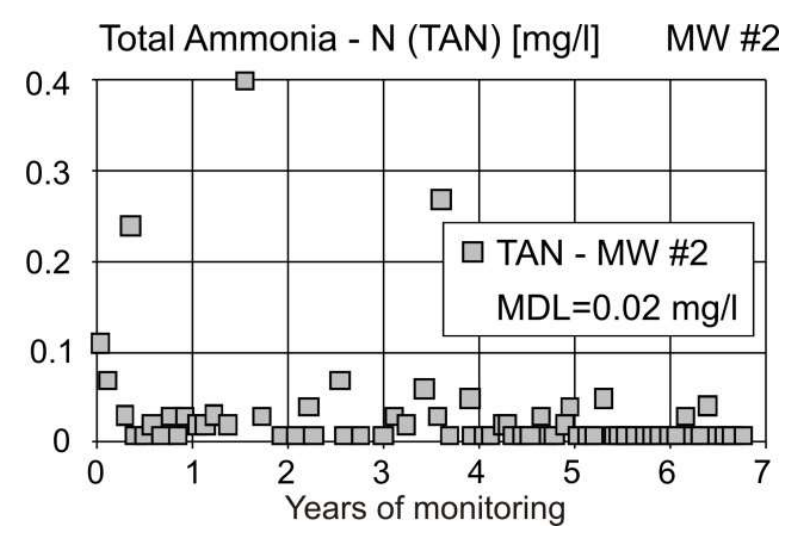

Fig. 9. Concentration of TAN in ground water of mid-system well MW \#2

Total Ammonia - N (TAN) [mg/l] $\quad$ MW \#3

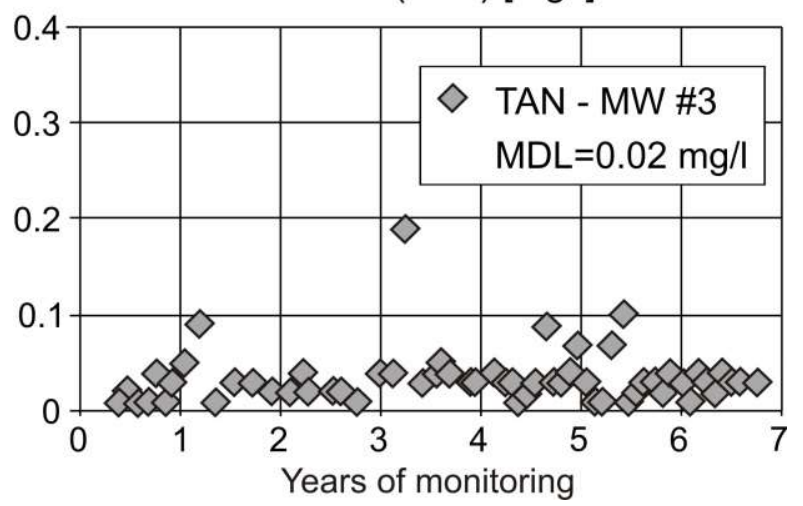

Fig. 10. Concentration of TAN in ground water of down gradient well MW \#3

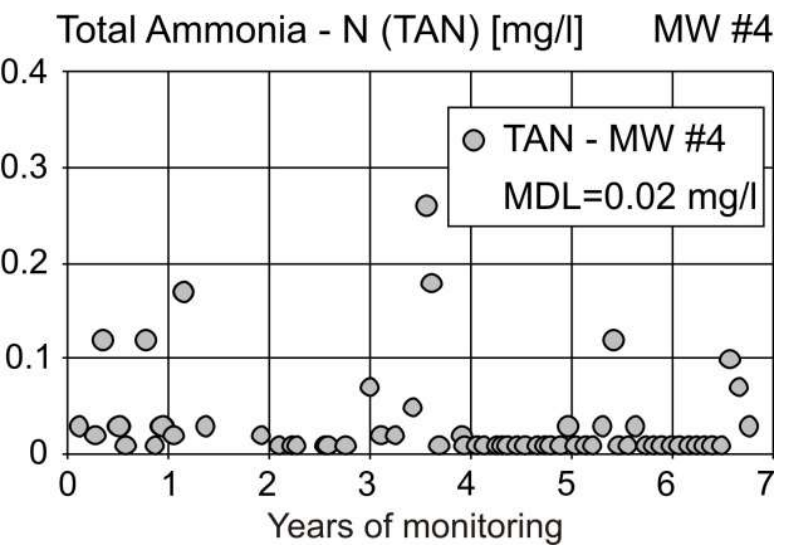

Fig. 11. Concentration of TAN in ground water of well MW \#4

\subsubsection{Conductivity}

Conductivity levels before production of man-made snow for each monitoring well are presented in Table 4.
Table 4. Conductivity of groundwater before snowmaking operation

\begin{tabular}{|c|c|c|c|}
\hline MW \#1 & MW \#2 & MW \#3 & MW \#4 \\
\hline$[\mu \mathrm{S} / \mathrm{cm}]$ & {$[\mu \mathrm{S} / \mathrm{cm}]$} & {$[\mu \mathrm{S} / \mathrm{cm}]$} & {$[\mu \mathrm{S} / \mathrm{cm}]$} \\
\hline 790 & 510 & 800 & 500 \\
\hline N/A & 480 & 510 & 310 \\
\hline 435 & 578 & 547 & 275 \\
\hline 410 & 540 & 547 & 510 \\
\hline 535 & 527 & 601 & 399 \\
\hline
\end{tabular}

The results of monitoring the ground water in the wells are presented in the graphs (Fig. 12, 13, 14, 15). Conductivity of the secondary effluent from the lagoon fluctuated in a range from $857 \mu \mathrm{S} / \mathrm{cm}$ to $1720 \mu \mathrm{S} / \mathrm{cm}$ with an average from the monitoring period of 11 years being about 1365 $\mu \mathrm{S} / \mathrm{cm}$. The conductivity of ground water in the up gradient monitoring well MW \#1 fluctuated in the range from $284 \mu \mathrm{S} / \mathrm{cm}$ to $879 \mu \mathrm{S} / \mathrm{cm}$, with an average of 432 $\mu \mathrm{S} / \mathrm{cm}$. During the monitoring process, a slight decrease in conductivity in this well was observed (Fig. 12)

Unfortunately, there is an increase in conductivity of ground water at the snow deposit site and at the border of the property. This is a typical increase of conductivity in ground water at irrigation fields. It is a sign that salts do not store in the soil. Moreover, conductivity is a good marker that indicates that ground water in the down gradient wells is influenced by the meltwater.

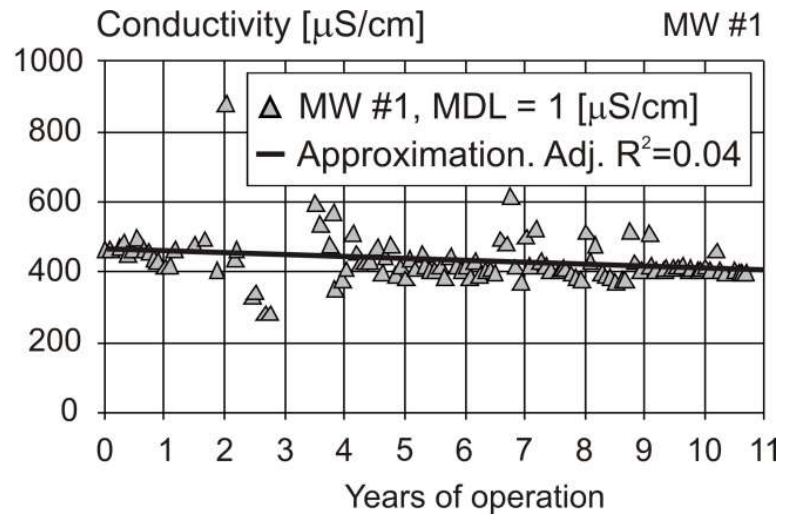

Fig. 12. Conductivity of ground water of up gradient well MW \#1

The conductivity of ground water in well MW \#2 fluctuated in the range from $439 \mu \mathrm{S} / \mathrm{cm}$ to $1210 \mu \mathrm{S} / \mathrm{cm}$, with an average value of $838 \mu \mathrm{S} / \mathrm{cm}$. The graph shown in Fig. 13 indicates that in the first years of the AFC process, there was a slight tendency for an increase of ground water conductivity in this location. After about 4 years, a slight decrease in conductivity was observed. Similar tendencies were noted for ground water conductivity in well MW \#3. The conductivity of ground water in well MW \#3 (Fig. 14) was generally in the same range as in well MW \#2 and oscillated from $406 \mu \mathrm{S} / \mathrm{cm}$ to $1180 \mu \mathrm{S} / \mathrm{cm}$, with an average value of $833 \mu \mathrm{S} / \mathrm{cm}$. The conductivity of ground water in well MW \#4 was slightly lower than in well \#2 and \#3 and 
ranged from $408 \mu \mathrm{S} / \mathrm{cm}$ to $1290 \mu \mathrm{S} / \mathrm{cm}$, with an average value of $731 \mu \mathrm{S} / \mathrm{cm}$. However, although the plotted points exhibit a fair amount of variation, the graph, for the monitoring period, shows a slightly increasing trend (Fig. 15). These conductivity values did not imply risks for vegetation yields or changes of soil texture.

Conductivity $[\mu \mathrm{S} / \mathrm{cm}]$

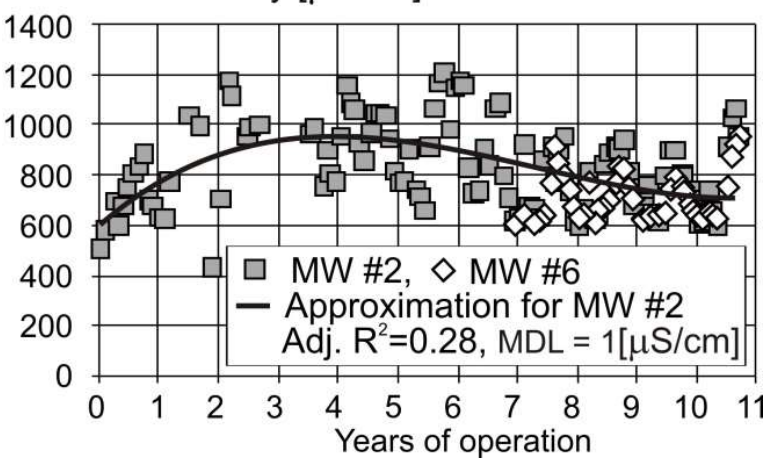

Fig. 13. Conductivity of ground water of both wells MW \#2 and MW \#6

\section{Conductivity $[\mu \mathrm{S} / \mathrm{cm}]$}

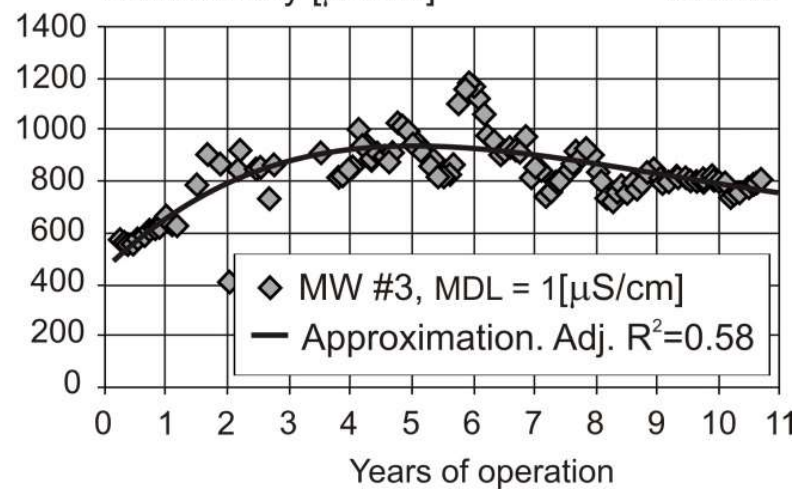

Fig. 14. Conductivity of ground water of down gradient well MW \#3

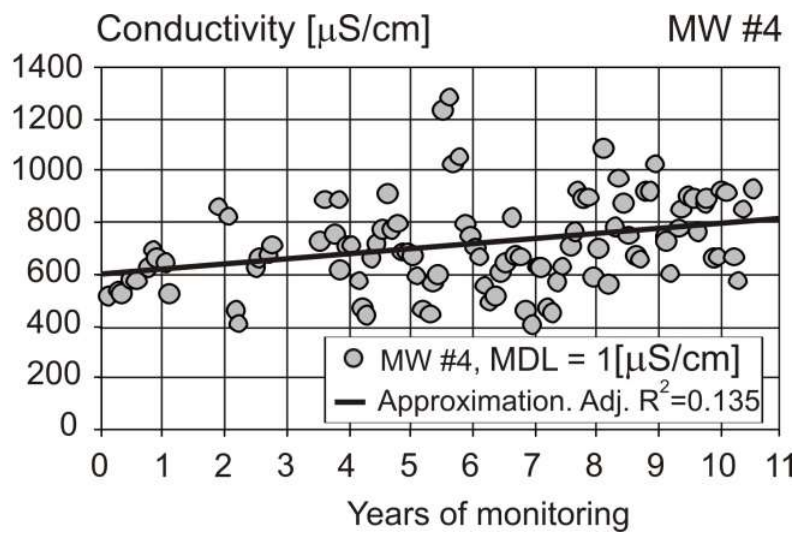

Fig. 15. Conductivity of ground water of mid-system well MW \#4

For the approximation of data as well as calculation of Adj. $\mathrm{R}^{2}$, the software TableCurve $2 \mathrm{D}$ was used.

\section{Conclusion}

The movement of melt water in the pores of the soil creates favourable conditions for its purification. The soil matrix acts as a deep-bed bio-filter and has a tremendous potential to treat melt water from secondary effluent. In the top layer of the soil, essentially all suspended solids, biodegradable materials, microorganisms can be restrained and biodegraded and picked up by vegetation as nutrients.

The method of freezing in the form of snow proved to be effective in reducing the concentration of many undesirable compounds and through the agglomeration of colloidal particles, in significantly improving the clarity of effluent in the form of melt water.

Dissolved phosphorus does not leachate into the ground water table because it is immobilized in the soil matrix and absorbed by microorganisms and vegetation. The concentration of sodium bicarbonate extractable phosphorus decreases significantly with increasing soil depth. At a depth of about $0.5 \mathrm{~m}$ and greater, it was below the MDL.

Dunne et al. [26] suggested that the soil could still release $\mathrm{P}$ under flooded conditions. The location area of the MW \#3 monitoring well was sometimes flooded in the spring. However, no phosphorus was detected during monitoring in filtered groundwater samples from this well.

After several years of monitoring of the atomizing freeze crystallization process, there were no reported elevated concentrations of $\mathrm{NO}_{3}^{-}-\mathrm{N}$ in down gradient monitoring wells. In most samples, the nitrates $\left(\mathrm{NO}_{3}{ }^{-}-\mathrm{N}\right)$ were not detected in both down gradient wells: MW \#3 and MW \#6. These wells were located behind the buffer zone at the property boundary. $\mathrm{NO}_{3}{ }^{-}-\mathrm{N}$ was detected near places of snow deposit site but it was not reported higher than 4 $\mathrm{mg} / \mathrm{l}$ in Well \#2 and not higher than $5.3 \mathrm{mg} / \mathrm{l}$ for well MW \#4 (Fig. 5 and 7). This phenomenon can be explained by the fact that significant portions of the nitrate can be taken up by trees and other vegetation growing at the snow deposit site and in the buffer area. Moreover, the soil at the down gradient location was periodically saturated by meltwater and an anaerobic state created favorable condition for the denitrification process.

Summer and winter land applications of effluent allow for partial ammonia volatilization during atomization, the removal of $\mathrm{N}$ through biological uptake, nitrification and denitrification. During atomization in low ambient temperatures air droplets are frozen very fast and ammonia is trapped inside the ice during snow storage. However, the phenomenon of ice crystals metamorphism creates favorable conditions for slow volatilization of ammonia and other trace gaseous compounds. No odor was detected during snow storage and melting.

Average conductivity of ground water in the monitoring well MW \#2 increased from $527 \mu \mathrm{S} / \mathrm{cm}$ to 837 $\mu \mathrm{S} / \mathrm{cm}$. Similar increases of average values from 601 $\mu \mathrm{S} / \mathrm{cm}$ to $833 \mu \mathrm{S} / \mathrm{cm}$ and from $399 \mu \mathrm{S} / \mathrm{cm}$ to $731 \mu \mathrm{S} / \mathrm{cm}$, were noted for wells MW \#3 and MW \#4, respectively. As 
monitoring well MW \#6 was installed later during the operation, there is no data for conductivity of ground water for this well before commencement of the snowmaking operation.

AFC process can be adapted to existing site conditions in order to achieve optimal results. One of such modifications could be a drainage system that would allow, after land application and deep-bed bio-filtration in soil profile, surface discharge of processed effluent in the form of melt water.

\section{Symbols}

AFC - Atomizing freeze crystallization.

MDL - Method detection limit.

MW - Monitoring well.

N/A - Not available

TAN - Total ammonia as nitrogen.

\section{Acknowledgement}

Publication supported by the Polish Ministry of Science and Higher Education as a part of the program of activities disseminating science from the project „Organization of the First International Science Conference - Ecological and Environmental Engineering”, 26-29 June 2018, Kraków.

The assistance of Jeffrey A. White of Northern Watertek Corp.(Ottawa, Canada), in the explanation of several doubts during the preparation of this paper is gratefully acknowledge.

\section{References}

1. Tzanakakis V. A., Paranychianakis N.V., Angelakis A. N., Ecol. Eng., Vol. 35, 10, 1485-1492, (2009).

2. Wright K.R., J. Civ. Eng. - ASCE, 88-89, (1976).

3. Huber D., Palmateer G., Snowfluent - A join experimental project between Southwest Region of the Ministry of the Environment and Delta Engineering in the storage and renovation of sewage effluent by conversion to snow. MOE Rep. ON, Canada, (1985).

4. White J.A., Treatment of sewage by conversion to snow - Full scale operation - Bruce, Report, Delta Engineering, ON, Canada, (1990).

5. White J.A., Evaluation of freeze-crystallization process in full scale pilot project - Carrabassett Valley, Report, Delta Engineering, Ottawa, Canada, (1994).

6. Sego, D.C., Use of Natural freeze-thaw processes to separate and treat mine waste water. Proceedings from IWC-96, (1996).

7. Szpaczynski J. A., White J. A., Experimental studies on the application of natural process of snow metamorphism for concentration and purification of liquid wastes. Water Environment Federation and Purdue University Industrial Wastes Technical Conference, St. Louis, Missouri, USA, (2000).

8. Sego, D.C., D. W. Smith, W. Gao, J. Environ. Eng. Sci., 2(5), 325-334, (2003).

9. Gao W., Desalin., 268, 170-173, (2011).

10. Szpaczynski J. A., Przem. Chem., 1,(9), 82-86, in Polish. (2017)

11. Szpaczynski J. A., Biochemical evaluation of AFC meltwater - Carrabassett Valley. Report, Delta Engineering, Ottawa, Canada, (1995)

12. Gibson T., Compress Air, Dec. 18-23, (1996).

13. White J. A, Szpaczynski J. A., Landfill Leachate treatment and disposal - Chester. Report, Northern Watertek Corp., Ottawa - Vars, Canada, (2007).

14. Colbeck S.C., J. Geophys. Res., 88, 5475-5482, (1983).

15. Szpaczynski J. A., White J. A., Cote C. L., Chem. Process Eng., 38, No. 2, 249-264, (2017).

16. Taft R.A., The advanced waste treatment research program. Report, U.S. Department of Health, Education, and Welfare, (1965).

17. Baker R.A., Water Res., 1, 61-77 and 97-113, (1967).

18. Vesilind P.A., Martel J.C., J. Environ. Eng., 116(5), 855-862, (1990).

19. Vose J. M., G. J. Harvey, K. J. Elliott, B. D. Clinton, Measuring and modeling tree and stand level transpiration, in Phytoremediation: Transformation and Control of Contaminants. Ed. S. C. McCutcheon and J. L. Schnoor, (2004).

20. Avery C. C., Dexter L. R., Wier R. R., Delinger W. G., Tecle A., Becker J. R., Where has all the snow gone? Snowpack sublimation in Northern Arizona. Western Snow Conference, Wyoming, 18-23, (1992).

21. USDA-CSREES Regional Committee, Methods of Phosphorus Analysis for Soils, Sediments, Residuals, and Waters, Southern Cooperative Series Bulletin No 396, (2000).

22. Rice E. W., R.B. Baird, A.D. Eaton, L.S. Clesceri, editors, Standard Methods for the Examination of Water and Wastewater, 22nd Edition, (2012).

23. Tan H. K., Principles of soil chemistry, CRC Press, $4^{\text {th }}$ ed., (2011).

24. Tzanakakis V. A., Paranychianakis N.V., Angelakis A. N., Ecol. Eng., 37, 11, 1757-1764, (2011).

25. EPA Report, EPA-625/4-76-010. (1976).

26. Dunne E. J., Clark M. W., Mitchell J., Jawitz J. W., Reddy K. R., Ecol. Eng., 36, 1392-1400, (2010). 